ABSTRACT John Hyacinth de Magellan, a Portuguese physicist who lived in London in the last 26 years of his life until his death in 1790 , has his religious life and personal views analyzed in the light of new and previous research. His personal religious evolution is followed throughout his life as well as his views about personal, social and ethical matters. The influence of the religious practice in Portugal during the first half of the 18th century and of the reactionary ideas prevalent in the country at that time was certainly decisive to his emigration to England, since he was a cultivated man that had a strong will to devote himself to scientific matters. Through his correspondence and other sources, it is confirmed that he never gave up Catholicism, though his religious practice was not always strict and orthodox, and sometimes it seemed to be somewhat similar to Protestantism.

Key words 18th century; physicist John Hyacinth de Magellan; moral issues.

RESUMO A vida religiosa e as opiniões pessoais de João Jacinto de Magalhães, o físico português que viveu em Londres nos últimos 26 anos da sua vida até a sua morte em 1790, são analisadas à luz de novas e anteriores investigações. A sua trajetória religiosa é seguida ao longo da sua vida, bem como as opiniões que manifesta acerca de assuntos de natureza pessoal, social e ética. A influência da prática religiosa em Portugal durante a primeira metade do século XVIII e as ideias retrógradas que prevaleciam então no país foram certamente decisivas para a sua emigração para a Inglaterra, pois era um homem culto com uma forte vontade de se dedicar às matérias científicas. Através da sua correspondência e de outras fontes, confirma-se que manteve a fé católica, embora a sua prática nem sempre fosse estrita e ortodoxa e, por vezes, parecesse próxima do protestantismo.

Palavras-chave século XVIII; físico João Jacinto de Magalhães; aspectos morais.

\section{The private life and}

character of physicist

John Hyacinth de Magellan

(1722-1790)
MANUEL FERNANDES-THOMAZ

Universidade de Aveiro

\section{Introduction}

The present work aims at throwing light on the views, sometimes contradictory, of some biographers, on the religious life and attitudes of $18^{\text {th }}$ century John Hyacinth de Magellan 1 through the course of his life, either in the earlier period, in Portugal, and in the later part, in London and the rest of Europe.

The private life and views of a historical man of science, though not shedding directly light on his scientific work, contribute to understand his character and to explain some of his attitudes and lines of action in life. We know that it is not easy, in most cases, to get an insight in the personal thinking of an historical figure due to the fact it is difficult to find out the necessary sources and, consequently, the explanations for some ways of thinking or acting escape the analysis of the historian. In the present case, we have a set of private letters (seventy five, in number) where our scientist opens his soul and mind to his friend Ribeiro Sanches ${ }^{2}$ and from them we can extract a reasonably clear picture of his character and his views about many subjects, sometimes very private, that are of importance to characterize his personality. Those letters, covering the years 1775 to 1783 , make a kind of diary that provides a means to achieve that insight. Opinions, thoughts and views on matters like religion, politics, social behaviour, morals, friendship and other subjects present in that set of letters are decisive to construct that picture. 


\section{Previous biographical notes about Magellan}

Let us see what his biographers say about his initial religious life and progression:

i) Starting by his first biographical note, the unknown person who wrote the obituary note in the Gentleman's Magazine ${ }^{3}$ writes: ". . formerly an Augustinian monk at Lisbon ..." and then: "He was a very mild Christian, having many years renounced the Popish faith." This is a quite important assertion since this note was written just after Magellan's death by someone who probably knew him well, though it contains various mistakes, like his place of birth and others. The statement that Magellan had renounced the Popish faith means, at least, that he acted in a way that gave that idea to others;

ii) In the Biographie Universelle of Michaud, ${ }^{4}$ the biographical note of Magellan, whose author was Weiss, only states that he: "prit l'habit monastique dans l'ordre de Saint Augustin ..." and nothing else;

iii) In the Nouvelle Biographie Universelle ${ }^{5}$, the author of the note, signed P., just says "Après avoir fait un long séjour dans les couvents de l'ordre des Augustins, dont il avait prit I'habit en 1723 ..." This was certainly a mistake because Magellan was born in 1722. Maybe the author wished to say that in 1733 Magellan entered the monastery, though in a preparatory college;

iv) In one of the earliest editions of the Dictionary of National Biography 6 the author of the biographical note, signed S.P.O., says: "He seems to have been brought up at Lisbon, where he became a monk of the order of St. Augustine,..." and then: "When forty years old he abandoned the monastic life in order to devote himself to wider philosophical research" and also: "He was buried in Islington churchyard, having many years previously renounced the Roman Catholic religion." There are many mistakes in this note and it seems that in some assertions it replicates previous notes;

v) Later, in the first decades of the $20^{\text {th }}$ century, the Portuguese researchers that studied the life and work of Magellan describe his religious options as follows:

a) Ricardo Jorge says ${ }^{7}$ in a very emotional way that "he changed the Augustinian habit for the more elastic secular cassock though this change did not appease the inquietude of his mind. Feeling the incurable ulcer of the open tonsure and that the cassock of Abbé tightened the seams, one day he tore it in pieces throwing the bits to the grounds of heresy." Later he says that "Magellan found in London his spiritual paradise on earth, he did not have to make a great effort in anglicizing himself and to greater integral conformity he converted to Protestantism: the canon regular, the translator of catechisms, evolved in Lutheran - the Abbé had been interred." ${ }^{8}$ In spite of the quality of the research on the history of medicine conducted by Ricardo Jorge about Ribeiro Sanches (and his friends, among whom Magellan was counted), the anticlerical atmosphere of the early $20^{\text {th }}$ century in Portugal was openly manifest and, above all, the sources of his sayings are not referred;

b) Maximiano de Lemos, ${ }^{9}$ also a good historian of Portuguese medicine, was not as emotional as the previous author about the matter and simply said that Magellan did not feel inclined towards the Augustinian habit and after insistent request he got from the Roman Curia a brief of secularization. This however did not satisfy his unquiet mind and he expatriated himself saying that he did it, like his ancestor Fernão de Magalhaens, "à cause de quelques désagréments qu'il essuya de la part des rivaux de son mérite." There are no mistakes in Lemos' biography of Magellan, but there are a number of unproven assertions.

c) Perhaps the best of the Portuguese biographers of Magellan before the late $20^{\text {th }}$ century was Prof. Joaquim de Carvalho, who wrote an extensive paper about a set of letters to Magellan that he found at the Bodleian Library. ${ }^{10}$ In the long introduction he says that Magellan "entered at eleven years of age to the congregation of the regular canons of Saint Augustine, of Santa Cruz of Coimbra, whose vows he professed with the name of D. João de Nossa Senhora do Desterro" and that "it was with that congregation's habit that the French navy officer and astronomer Gabriel de Bory (1722-1801) met him in Coimbra when he came purposely to Portugal to observe the solar eclipse of $26^{\text {th }}$ October of 1753 ". Further down, Carvalho says: "In an uncertain date, most probably between 
1756 and 1758, secularized but not deprived of ecclesiastical dignity, fact that seems not to have happened but later in England, on motivations that are also ignored, though they can be presumed ..." A footnote explains that the doubt about the loss of ecclesiastical dignity was not yet cleared at the time;

vi) In the second half of the $20^{\text {th }}$ century, the Dictionary of Scientific Biography, ${ }^{11}$ in the note about Magellan, the author, Stuart Pierson, says: "His family, who made an unproven claim to be descended from Ferdinand Magellan, sent him to an Augustinian monastery in Coimbra when he was eleven years old, and there he lived and studied for about twenty years, first as a novice and then as a monk. There was a scientific tradition among the Coimbra Augustinians (it is reported that they studied the works of Newton), and as a consequence Magellan became well enough versed in astronomy to serve as a guide for, and gain the friendship of Gabriel de Bory during the latter's visit to Portugal in 1751 to observe a solar eclipse. A few years later Magellan sought and received permission from Pope Benedict XIV to leave the order. From 1755 to about 1764, Magellan travelled through Europe, finally settling in England, where he resided for the rest of his life. At some point he was converted to Protestantism." There are several inaccuracies in this note that will be revealed in the course of the present paper;

vii) In the Conference held in Coimbra University on the 200"t anniversary of Magellan's death, the paper by Zilia de Castro, ${ }^{12}$ describes her thorough research on a number of issues concerning Magellan's religious life. She first speaks about "the entrance [of Magellan] in the Colégio de Santo Agostinho or da Sapiência, belonging to the Monastery of Santa Cruz and commonly called Colégio Novo, even among the members of the congregation community. He had then eleven years of age." The description of the rules for enrolment and continuation in the college included a preliminary examination before being placed in the adequate level of knowledge. "Whether or not related to the studies and the activity performed, the fact is that he [Magellan] asked for the ingress in the Congregation of the Regular Canons of St. Augustine," "completed the time prescribed for the noviciate" and then took the vows as Brother in the $23^{\text {rd }}$ of April, 1743. In the Easter of the following year he took the next congregational vows, becoming a regular canon and in 1751 was ordained priest. The secularization brief supposedly obtained from the Pope Benedict XIV did not break or suspend these last vows but simply the link to the congregation. He was entitled to receive the prescribed ecclesiastical annual revenue which he did not receive for many years, but finally received with the backward dues, as he says in a letter of $1787 .{ }^{13}$ This leads the author to say that "in this way the hypothetical conversion to Protestantism, sometimes mentioned, is definitely dismissed." She also makes interesting considerations about the ideological position of Magellan, suggesting that Magellan was sympathetic to the cultural values of Jansenism if not a Jansenist himself and consequently anti-Jesuitical. "In another context, without openly accusing the action of the Jesuits, John Hyacinth expresses ideas concerning the political value of religion and the legitimacy of intervention of governments whenever a vicious religious practice threatens the welfare of citizens." The article that we have been referring is perhaps the most complete study about the religious positions of Magellan at its date;

viii) The PhD thesis of Isabel Malaquias, ${ }^{14}$ of 1994, which is the most comprehensive research on Magellan's life and scientific work, gives in its $2^{\text {nd }}$ Chapter a review of some of the then known facts about Magellan's religious life, but as the thesis was not specifically about this matter it does not contain new significant facts on the topic of the present paper;

ix) In the biographical note by Rod Home, in the recent edition of the Dictionary of National Biography, ${ }^{15}$ which is supposed to be the most recent review of the main biographical events concerning Magellan it is said that "In 1733 Magellan entered the Augustinian college of Santa Cruz, the Colégio da Sapiência, at Coimbra. A decade later he joined the Augustinian order as Frei João de Nossa Senhora do Desterro, ${ }^{16}$ and later became a canon with the name of Dom João de Nossa Senhora do Desterro. The convent had an excellent library that included the works of Newton as well as the classics, and during twenty years there Magellan cultivated a love of science. Eventually he became dissatisfied with convent life, and in 1754 he successfully petitioned Pope Benedict XIV for a letter of secularization." and afterwards the author continues: "In Paris and in Portugal, Magellan, despite his secularization, long continued to de referred to as 'abbé'. He is reported to have been arrested in England for saying mass, which was still a felony. In later life he enjoyed the free-thinking atmosphere of Parisian intellectual life that so scandalized his friend Priestley when they visited Paris together. There are indications that he remained a Roman Catholic even though he was buried in an Anglican church- 
yard." This is by far the most complete and correct of the biographical notes of Magellan though some minor aspects are subject to change by the present work;

To the exception of the texts mentioned in vii), viii) and ix) none of the other biographers of Magellan indicate the specific sources for their statements about this aspect of his life, or simply replicate assertions of previous biographers. It is evident that the positions assumed by the various biographers are not totally in agreement. We wish to contribute with further historiographical elements to make this facet of Magellan's life clearer.

\section{The early life in Portugal}

John Hyacinth de Magellan (João Jacinto de Magalhaens in Portuguese) was born in Aveiro in the $22^{\text {nd }}$ of November, 1722 and 11 months passed he was orphan of mother and father. In fact, his mother died possibly as a consequent of the delivery five days after giving birth to his first son. The father died less than a year after, in 1723 , with 56 years of age. ${ }^{17}$

We don't know who took care of the newborn child and of the education of the little boy whose first years of life were almost certainly passed in his home town of Aveiro.

His entrance, at the age of eleven, in the Colégio da Sapiência at the Monastery of Santa Cruz in Coimbra, of the Order of St. Augustin, one of the most prestigious monasteries in the country for the quality of its teaching, ${ }^{18}$ is well documented. It is not known who took for him the decision of that entrance but possibly the influence of some relatives who were influent in the clerical milieus of Coimbra and Aveiro and also the fact that John Hyacinth possessed some assets that, in the future, could constitute the entrance dowry to the monastery might have helped the decision. ${ }^{19}$ Certainly also a level of intelligence and interest to learn above normal on the part of the adolescent must have had influence in the decision to enter and to be accepted into a college famous for its requirements and the high level of the studies that were practiced there.

In fact, the way followed in the Order, as prescribed in the old use, consisted of a proof of good morals, that is, to be known and considered of good breed, to make a promise of obedience to the rector and eventually to be examined before being placed in the most adequate class to his level of knowledge. ${ }^{20}$

His progression in the Order until he obtained the major orders in 1751, at the age of 29, thus becoming an Augustinian Canon Regular, that is a priest, is also established. ${ }^{21}$

The conditions and circumstances of his egression from the Order are not yet well known since the egression petition letter and the process that must have followed were not yet discovered as well as the exact date and terms of the final decision. However, a pretty correct approximation to those conditions can be established from existing documents, as we shall see ahead.

The egression is first referred by Gabriel de Bory in his report of the voyage made to Portugal in order to observe the solar eclipse of $26^{\text {th }}$ October, 1753. He says: "M. Magalhaens, alors Chanoine de Sainte-Croix, \& maintement Correspondant de cette Académie, fut chargé de nous montrer les curiosités du Monastère $\&$ de la Bibliothèque de I'Université; il s'en acquita avec beaucoup de complaisance \& de politesse. En 1744, il a obtenu du Pape Benoît XIV, un Bref pour sortir de sa Congrégation, \& après avoir voyagé en différens endroits de l'Europe, il réside \& cultive à Londres les Arts et les Sciences." ${ }^{22}$ Later, in a letter to Ayres de Sá e Mello, Portuguese Secretary of State for Foreign Affairs and War, Magellan refers "the Congregation of the Canons Regular of St. Augustine from where I am egress by force of a Brief of His Holiness." ${ }^{23} \mathrm{He}$ also refers in the same letter the value of the annual revenue that he was entitled to receive from the congregation according to the terms of the egression decision and that amounted to Rs. $30,000 .{ }^{24}$

It is important to recall that in the first half of the $18^{\text {th }}$ century the religious orders in Portugal (possibly also in other Catholic countries) were in a state of deep crisis and even scandal due to disobedience of the rules in what concerned 
clausura (cloistral confinement), chastity and praying obligations. This was in part due to the many religious vocations that were not genuine but certainly also due to the new ideas that flourished in Europe. The situation was so serious that the Pope appointed Reformers to the orders with the mission to re-establish the rules as they had been in their origin.

Though Magellan's petition for egression and the following process were not discovered yet, we found in the Portuguese National Archives a decree-letter of the Reformer General of the Augustinians of Santa Cruz, dated 30 ${ }^{\text {th }}$ of May, 1744, where he says: "having His Holiness given to me the faculty of granting licence to the canons, who have professed before the Reform, to egress to the clerical habit with revenue of the property and income from the same congregation leaving to our judgement to establish the referred licence to the several religious that asked it and today amount to the number of seventy two, arbitrating to each one the revenue of Rs. 30,000 each year paid in two instalments by St. John's day and Christmas ..."25

Another requirement established in the egression licence was that the egress canons after leaving the congregation should make themselves available to the highest church official (bishop or his representative) of the town where they would go to reside in order to be entitled to the congregational privileges.

The date of the above decision is the same as the date given by Bory (1744), but we know that Magellan took his highest vows in 1751 so that he was not among those 72 canons that were the object of the mentioned Reformer's letter and was certainly egress later than 1751. Nevertheless, the conditions of egression were those referred in the above letter. We know that in 1754 he was still considered a canon regular of the order. ${ }^{26}$ The cases of egression were extended for many years after these times. We found a number of very similar letters of egression in the seventeen eighties, which were similar in every respect except in the amount of the annual revenue that was updated to Rs. 36,000 , thus meaning an increase of $20 \%$.

Assuming that Magellan's process and conditions of egression were similar to those found in the archives, we can conclude that when Magellan emigrated to London a few years later he was not a regular canon, but was still a secular priest, dressing as a cleric, with full clerical powers and entitled to receive annually a revenue equivalent to about $f 550,00$ from his congregation, though in fact he only received this revenue more than 20 years later and endowed it to the Lisbon Academy of Sciences for a Prize on Agriculture. ${ }^{27}$

\section{The "tour philosophique" throughout Europe (c. 1758 - c. 1761)}

A few years after his egression from the Augustinians, which took place formally between 1754 and 1758 , Magellan went abroad in a "tour philosophique", as he called it, to visit France, the Low Countries, Rome and probably northern Italy and England. He must have been most of the time in Paris with Ribeiro Sanches the prestigious exiled Portuguese doctor who have settled there in 1747 after his stay in Russia. In fact Sanches helped Magellan financially as he acknowledged. ${ }^{28}$

During this tour Magellan published a few books, two translations and one edition of a famous work of a Portuguese $17^{\text {th }}$ century author. In the three publications there are indications of the evolution of Magellan's mind concerning religion. One of the translations is the Greek Grammar of Port Royal, ${ }^{29}$ an abbey that was perhaps the main stronghold, in France, of Jansenism and consequently of anti-Jesuitism, as well as anti-absolutism.

In the other book published by Magellan during the mentioned period, ${ }^{30}$ he writes a brief note about the life of the author, Frei Luiz de Souza, where he writes, in a footnote, that "for a long time some men of superior judgement claim... that to no one should be permitted to pass to the ecclesiastical or to the religious state without having before a long experience of the civil jobs and not before touching the 60 years of age." This comment means clearly that Magellan did not think to have entered the clerical state in the right moment and with the adequate disposition.

The other book he translated and published was an anti-Jesuit pamphlet, ${ }^{31}$ written by a French egress capuchin. ${ }^{32}$ 
The date of publication of this translation, as well as of the original is 1763 , but it may have been prepared for publication earlier since we know that the author, Abbé Platel had been visiting Lisbon as early as $1761,{ }^{33}$ possibly at the service of the Prime minister's anti-Jesuit policy. This translation and publication may suggest that at the time, Magellan was in good terms with the enlightened political views of the Count of Oeiras, late Marquis of Pombal.

\section{The London period (1763-1790)}

It is known that, in the early years of his arrival in London, Magellan was treated and known as Abbot Magalhaens (or Abbé Magalhaens and Abade Magalhaens, for his French and Portuguese speaking friends) and in this way he was addressed by his friends and correspondents or those who referred to him in their correspondence. This is true at least for the first years of his stay in London, that is, until the mid seventies. ${ }^{34}$

A relevant episode occurred in 1768, ${ }^{35}$ which shows that Magellan was considered a priest with full clerical powers. In fact, at that time it occurred the trial of five men indicted by an informer for having said mass, which was then a felony. Among the five men was John Hyacinth de Magalhaens. It may be the case that he had presented himself to the Bishop, as highest Catholic authority in London, in order to comply with the requirements of the egression brief mentioned above. The Bishop was Dr. Richard Challoner a man of great prestige among Catholics and non Catholics. The trial is reported in great detail in a book about Bishop Challoner's life. ${ }^{36}$ The informer, William Payne, had previously received the prescribed reward of one hundred guineas for the indictment of other priests and tried to indict Bishop Challoner himself and six others based on the same fault, but they had found that he forged some copies of subpoenas and he relinquished the prosecutions in return for not disclosing that situation. However, he carried on the prosecutions against others with unremitted vehemence ${ }^{37}$ He brought them all (among them Magellan) "to their trial in the Court of King's Bench at Westminster: but as he could not prove that any of them were Priests; or that the Functions which he saw them perform, were not such as might be performed by persons who were not in Priest's Orders: they were all acquitted." ${ }^{38}$ The Right honourable William, Earl Mansfield, ${ }^{39}$ Lord Chief Justice of the Court of King's Bench at Westminster, stood in behalf of the accused and pleaded not guilty, which was followed by the Jury. He even accused the informer saying that "it is money; and money alone, that makes Payne become informer. He has got One Hundred Pounds already by informing, and now sets no bound in his Avarice; he has left off his Carpenter's trade to become Informer." ${ }^{40}$ The persecution against Catholics was alleviated by an Act of Parliament passed in $1778^{41}$ (Sir George Savile's bill) that relieved "his Majesty's Subjects professing the Popish Religion, from certain Penalties and Disabilities imposed on them by an Act of the Eleventh and Twelfth Years of the Reign of William the Third," ${ }^{22}$ that is 1700-1701. However in 1779, Lord George Gordon organized the Protestant Association and instigated a great riot in London, which took place in June 1780, of many thousands of people (ca. thirty to fifty thousand) dressed and armed like an army that marched over the Houses of Parliament to present a petition against Emancipation (the Gordon riots). ${ }^{43}$ The mob attacked many public buildings and Catholic chapels were destroyed. ${ }^{44} \mathrm{He}$ was then put to trial at the Court of King's Bench under the accusation of high treason on the $5^{\text {th }}$ of February 1781 . The Right Honourable Earl Mansfield was Chief Justice. Thanks to the defence he was acquitted.

After the Gordon riots a period of a certain tranquillity and tolerance succeeded, though only by the Second Relief Act of 1791, Catholic Chapels were permitted still with some restrictions.

This situation might have been the cause for Magellan to look for religious institutions in more secure countries (from the point of view of the tolerance towards Catholics) to be aggregated to. It is well known that Magellan cultivated good relations in Flanders. He knew, visited and corresponded with the Duke of Aremberg, ${ }^{45}$ John Needham, ${ }^{46}$ Nathaniel Pigott, ${ }^{47}$ Jean Chevalier, ${ }^{48}$ some professors at Louvain University, ${ }^{49}$ the Counsellor Takoen of Malines ${ }^{50}$ and others. It seems therefore a likely solution that he looked for a more stable position in that country, which was Catholic at the time. The fact is that by 1785 , Magellan asked to join the Chapitre Royal of St. Vincent de Soignies ${ }^{51}$ in the Austrian Low Countries, where he became a Canon ${ }^{52}$ until his death. 
These are facts that have been subject to scrutiny by religious entities and that assure us that Magellan assumed himself (and was considered by the religious authorities as) a Catholic priest.

\section{Magellan's opinions on religion and moral issues}

The early views of Magellan about his religious status are reflected in the positions we show in Section 3.

As his life passes he develops a strong criticism towards several aspects of Catholic religious practice, especially in Portugal. Though these critical views have probably been made clearer in his mind by the more open atmosphere he lived in Europe, and particularly in London, it is a fact that he had already the same sentiment in earlier times, though not so explicit.

These views are more apparent in his correspondence with Ribeiro Sanches since this was a close friend and a Portuguese with whom he shared openly his opinions about the Portuguese situation. Unfortunately we only have the letters from Magellan to Sanches as the Sanches letters to him were not yet found. ${ }^{53}$ In any case, for the purpose of the present paper Magellan's letters are more relevant than their counterparts. Nevertheless, we also find some interesting information in his letters to other people.

First we point out Magellan's opinions against bigotry and all kinds of religious immoderation in the Portuguese society of the time, to which he is strongly and ironically opposed. A few examples illustrate his opinions. After the death of King Joseph and consequent fall of his Prime Minister, the Marquis of Pombal, his daughter Mary I, who succeeded him, who was a very religious person. ${ }^{54}$ Magellan says ironically to Sanches in August 1777: "You don't know how much I have laughed with the rosary, sung by our soldiers. It is said that the Queen never signs any decree or order, without having her hand covered with relics of saints. It is the safest way to have the heavens on her side in everything." and again in February 1778:" I was pleased that Chevalier ${ }^{55}$ goes, like the duck to the water, to his greatly desired Lisbon: may God help him to sing the rosary, \& to run the Stations of the Cross. The day before yesterday I met an Englishman who arrived from Oporto, and told me that he saw there to ordain two thousand clergymen at a time. What a splendid show ...!"

Sometimes Magellan shows sympathy for the protestant philosophy and for Luther himself. In effect, this is what may be inferred from the following extracts taken from letters to Ribeiro Sanches dated July 1775 and July 1776 respectively: "Everything is going well and better all the time, because I know how to take the best party, \& take it from everything, with the sprinkling powders of the martinian philosophy that is my Mother Celestine" ${ }^{\prime 56}$ and "What do you think of the temptation for a stoic like me, who abjured all the Philosophy of Pangloss, ${ }^{57} \mathrm{~g}$ doesn't follow but that of the great Martin ...!"58

However, though sympathizing with Luther's ideas, he states very clearly that he is not a Protestant at least in two instances. First in the letter he writes to Sanches dated from Brussels in November 1776 where he tells one episode of his passage through Antwerp: "The $7^{\text {th }}$ I took the stage-coach at 4 in the morning, $\&$ arrived to Breda, before the gates were open I entered immediately into the coach to Antwerp where I stayed that night. It was Friday and I couldn't find anything for dinner except salted fish. Damned Austrian hypocrisy! Fortunately the innkeeper in Antwerp took me for what I am not (Protestant) and gave me to dinner a piece of cold veal in my room." Magellan states very clearly that he is not a Protestant, but on the other hand he shows no respect for the Catholic rule of not eating meat on Fridays.

Years later, in a letter to James Watt dated 22 ${ }^{\text {nd }}$ December 1783 he says: "But the chief of these lines, is to beg you the favour of letting me know $\mathrm{y}^{\mathrm{r}}$. ideias ${ }^{59}[\mathrm{sic}]$ about the general Philal. Weights and measures: because altho' I am a Papist (not very strict indeed! as our good friend $D^{r}$. Priestley may testify), nevertheless I dont pretend to be a Pope, viz. infallible: and no doubt that your ideias ${ }^{60}[\mathrm{sic}]$ on the subject may have some thing at least which will improve my proposal. Be then so kind as to let me know what they are for public good, and mutual satisfaction."

We can therefore say that Magellan considered himself as a Catholic, though not strict and orthodox in his way of thinking, since he felt free to adopt the principles of his own mind even if these belonged to other confessions, namely 
Protestant. This he did by principle that is because he thought it was more correct. A different situation occurred with the moral attitudes he took in his private life ${ }^{61}$ since he did not comply with the moral obligations of the Catholic religion and even less with his responsibilities of being a priest. This he attributes to his weakness as in the letter he writes in April 1778 with anger due to someone that tried to slander him before Sanches for having had connections with Dr. Williams. ${ }^{62}$ He says: "Therefore I repeat, I am very obliged to that Mr. Gensfoutre ${ }^{63}$ for not being able to invent against me a calumny less easy to clean. If he had said that he saw me over my Nelly, or Fanny or any other of my acquaintances; then yes I might have some trouble to excuse for this weakness, of which I wish you could still be guilty now."

Magellan's ideas are firmly opposed to any kind of oppression and indefectibly in favour of liberties. His invectives towards the Inquisition are common in his letters as the one he writes to Sanches in August 1777 where he criticizes the situation in Portugal in very harsh terms: "Fortunate government...! I was also told [in the street, because you know well that in minister's house there are never any news to be told $]^{64}$ that a lampoonery has been circulating whose meaning is the following = the king is a saint: the queen a bigot: the minister leaves everything without solution: between the two evils choose Pombal. = after all here we will be far away looking at the disorder until everything goes into the mouth of Spain. It seems to me that I see this far Dr. Sly, with his beads in hand, the twisted neck, serving at mass, \& running the Stations of the Cross in Lisbon with all the noble dames, my ladies...! May god wills that fire is not set on the sanbenito; ${ }^{65}$ since the Inquisition \& the monks soon will return to their zenith."

In September 1778, he laments those who fall in the hands of Inquisition, like that student of the University of Coimbra: "Also arrived here a Mr. Bezerra ${ }^{66}$ student of the University of Coimbra, who ran away for not falling in the holy Inquisition's hands, because he is a naughty man who knows the French \& English languages, had lessons of Voltaire, Rousseau, and other authors rather more spirituous than spiritual. I dined with him at our Envoy's home for whom he had brought letters: \& we are all aware of the way things happen in that blessed country. Here I was told that crooked Alvares ${ }^{67}$ makes himself a fool, more than he really is: and so everyone has to behave in order to escape the persecution of the fanatic \& roguish hypocrites. But let us turn the pages, \& let the sea snore, since we are afar safe \& sound." Similar commentary he makes about the professor of mathematics Anastácio da Cunha:" This letter shall be delivered to you by Mr. João Bezerra son of Lisbon, and student of our longing University of Coimbra, who came to anchor in London, before experimenting the fate of his companion $\&$ close friend, professor of the same University, Joze Anastasio, ${ }^{68}$ to whom the Holy Inquisition condemned to the cloister of the fathers of the Oratory, because he had the misfortune of the good taste in the lesson of Voltaire, Rousseau, \& other similar vile ones of the monastic empire." Another student had fled from Portugal due to inquisitorial persecution: "A few days ago it arrived here a s[tude]nt I suppose already formed in Coimbra who is escaping from the Inquisition, because he read prohibited books \& for having suggested to a novice that he was freemason. He is Brazilian, but I don't know if he has anyone to assist him here with monthly allowances." Finally he shows to be sceptical towards the reforms of the Inquisition: "The monks and the clergymen enjoy themselves of the present form: which may perhaps finish sooner than they imagine. It is here known that the great reforms of the Spanish Inquisition are no more than a political satyr that some superior genius wished to make. I \& a great number, take this lie like the little fish of St. Anthony."

Magellan expresses his views against tyranny in several instances, as for example when he meets the son of the deposed Prime Minister, the Marquis of Pombal described in a letter to Sanches of May 1783: "Here is the Count of Oeiras, son of the famous Marquis of Pombal, to whom I hope to give a good beating of punches when I cross with him in the Elysium for his tyranny; however the son who is here is very different from his Father, in almost everything: but has a very kind heart and character..." The same sentiment is shown by the attitude he takes on the occasion of the Royal Society's troubles about the position that a few members take against its president Sir Joseph Banks for his will to manipulate the rules in order to make elect a number of his friends in a manner they considered dictatorial. ${ }^{69}$

He laments that in England to live and work were deteriorating and prophesizes it in the following way in a letter again to Sanches dated from London in June 1777: "Here things go like hell. Separated America, will be the sole asylum for philosophical spirits, as soon as peace is done: since it is necessary that finally it is done at least when the lack of this great amount of money in England begins to be felt". Magellan was anti-colonialist as he recalls to Sanches 
in a letter of April 1778 saying: "The war doesn't give me any embarrassment. If I had gone to America, as I wished 10 or 12 years ago, but you advised me not to do so; then yes I would be now captain at least of some company of Americans." Many of his friends were also against the American war, like Lord Shelburne, Dr. Price, John Fothergill, and many others.

\section{Conclusion}

John Hyacinth de Magellan had a rather peculiar religious trajectory encompassing the following aspects: i) being sent to the Monastery of Santa Cruz in Coimbra in his childhood without his consent and awareness of what it meant, it was only at his adultness that he realized he had no vocation for religious life; ii) he left the Augustinian congregation but kept his vows as a priest, being entitled to perform his priestly duties and to receive an annual revenue; iii) in contact with different views and religions he assumed a critical attitude towards the Catholic church and its practice, especially its exaggerations and distortions; iv) his private life did not conform with his duties and obligations as a priest, particularly in what concerns his chastity vows; v) as a consequence of his open mind he defended liberties and was against all types of oppression, like Inquisition, absolute power or dictatorial attitudes and colonialism.

\section{Notas e referências bibliográficas}

1 John Hyacinth de Magellan (1722-1790), whose Portuguese name was João Jacinto de Magalhães (he signed João Hyacintho de Magalhaens Leitão, but he later dropped the last name, Leitão), was born in Aveiro, Portugal, and emigrated to London in 1763, becoming F.R.S. in 1774 after being correspondent of the Paris Academy of Sciences in 1771 for his work on scientific instruments. See the biographical note of Rod Home, in Oxford dictionary of national biography: in association with the British Academy: from the earliest times to the year 2000, Vol. 36, OUP, 2000.

2 António Nunes Ribeiro Sanches (1699-1783), Portuguese doctor of Jewish origin who studied medicine in Salamanca, then in London and finally in Leiden with Boerhaave, Gaubius, van Swieten and others. Boerhaave recommended him to Russia on demand from the Russian authorities and there he held very important positions culminating with being doctor of the empress, what allowed him a life pension.

3 Gentleman's Magazine, February, p. 184, 1790.

4 Biographie universelle ancienne et moderne, Tome 26ème. Paris: chez L. G. Michaud, 1820.

5 Nouvelle biographie universelle ancienne et moderne. Paris: Ed. F. Hoefer, Firmin Didot, 1852.

6 Dictionary of national biography, 63 vols. London: L. Stephen and S. Lee Eds., 1882-1900.

7 JORGE, Ricardo. Amigos de Ribeiro Sanches - J. H. de Magellan. In: Medicina Contemporânea, Lisboa, 1910.

8 Quotations from Portuguese texts, namely the letters to Sanches, are translations. Only texts written in French we leave as they are in the originals.

9 LEMOS, Maximiano de Lemos. Estudos de história de medicina peninsular. Porto, 1916.

10 CARVALHO, Joaquim de. Correspondência científica dirigida a João Jacinto de Magalhães (1769-1789) - Contribuição para o seu epistolário. Revista da Faculdade de Ciências da Universidade de Coimbra, vol. XX, Coimbra, p. 93-283, 1952.

11 GILLISPIE, Charles C. (Ed.). Dictionary of scientific biography. 16 vols. New York: Charles Scribner and Sons, 1970-1980.
12 CASTRO, Zília Maria Osório de. João Jacinto de Magalhães na sua época. 'Luzes' e 'Trevas' do Pombalismo. João Jacinto de Magalhães (John Hyacinth de Magellan) Conference - On physical sciences in the XVIII century, University of Coimbra, November, 1990.

13 Letter to Magellan's cousin José de Magalhães Castelo-Branco, dated 1787-10.16, referred by Cruz Malpique in his paper. MALPIQUE, Cruz. No signo dos "estrangeirados". João Jacinto de Magalhães, natural de Aveiro, sócio da Academia das Ciências de Paris e da Real Sociedade de Londres (1722-1790), Arquivo do Distrito de Aveiro, 37, p. 32, 1971.

14 MALAQUIAS, Isabel Maria Coelho de Oliveira. A obra de João Jacinto de Magalhães no contexto da ciência do séc. XVIII. PhD thesis, University of Aveiro, Aveiro, 1994.

15 HOME, Rod. Biographical note. In: Oxford dictionary of national biography: in association with the British Academy: from the earliest times to the year 2000, 60 vols., OUP, 2004

16 Brother John of Our Lady of the Exile.

17 Manuel Fernandes Thomaz. João Jacinto de Magalhães e a sua ascendência. Revista Lusófona de Genealogia e Heráldica N. ${ }^{0} 2$ (2007) 165-180. In this study the ancestors of Magellan were investigated until the generation level of Fernão de Magalhaens, the navigator, that is, until the earliest part of the $16^{\text {th }}$ century.

18 For many years, the Prior of Santa Cruz was, by inherence, the Chancellor of the University of Coimbra.

19 See note 17

20 See ref. 12.

21 The taking of the different levels of orders are documented in the Archives of the University of Coimbra, as previously referred (Ref. 12).

22 BORY, Gabriel de. Suite du voyage fait par ordre du roi, en 1753, à la côte de Portugal \& à lî̀le de Madère. Seconde partie. Section première. Mémoires de l'Académie Royale des Sciences de Paris, 1772.

23 Letter to Ayres de Sá e Mello of 1784.02.17.

24 Rs 30,000 was then equivalent to c. $£$ 8,00 (Cálculo dos cambios de Portugal 
com varias praças eatrangeiras. Lisboa, 1792), and presently to c. $£ 550,00$.

25 Portuguese National Archives of Torre do Tombo: Sta Cruz de Coimbra, Liv ${ }^{0}$ 67, ff. $138 \mathrm{v}-141$.

26 In a notary decision about some of his old property, passed in the monastery with the date of $4^{\text {th }}$ September 1754 , he is still designated by his monastic name.

27 Letters to Ayres de Sá e Mello of 1784.02.17 and 1785.04.05. Ayres de Sá e Mello was the Portuguese Secretary of State for Foreign Affairs.

28 ANDRY, Charles-Louis-François. Catalogue des livres de feu M. Ant. Nunez Ribeiro Sanchè Paris, 1783. Charles-Louis-François Andry (1741-1829), French doctor, worked in hospitals, was a member of the faculty of medicine and of the Société Royale de Médecine. He wrote a biographical note on Sanches' life that appeared in the above mentioned Catalogue written for the auction of Sanches library. In the copy of this book that exists in the Public Municipal Library of Porto, there are a great number of written notes by Magellan's hand where he states the mentioned fact and many other interesting circumstances of his relation with Sanches.

29 Novo Epitome da Gramatica Grega de Porto-real. Lisbon, 1760.

30 SOUZA, Frey Luiz de. Vida do veneravel D. Frei Bartolomeu dos Mártyres da Ordem dos Pregadores. Paris, 1760.

31 PLATEL, Abbé. A fé dos catholicos: obra dirigida a instruir e confirmar na sua crença de catholicos. Lisbon, 1763. The French original was also published in 1763 in Lisbon.

32 Pierre Parisot (1703-1769) used different names as Curel-Parisot, Père Norbert von Lothringen and Abbé Platel.

33 Gazeta de Lisboa, January 13th, 1761.

34 For instance, in the Journal of Ribeiro Sanches, Magellan is mentioned by Sanches as Abbé until 1774

35 HOLT, Anne. A life of Joseph Priestley. London: O.U.P., 1931; GIBBS, F. W. Joseph Priestley, adventurer in science and champion of truth. London, 1965.

36 BARNARD, James. The life of the venerable and right reverend Richard Challoner, D.D. bishop of Debra, and V.A. collected from his writings, from authentic records, and from near twenty years personal acquaintance with him. London, 1784. Richard Challoner (1691-1781), bishop of Debra and Vicar Apostolic of the London district, was a prestigious Catholic bishop. There have been attempts to his beatification.

37 lbid., p. 165.

38 lbid., p. 166.

39 William Murray (1705-1793), raised to peerage as Baron Mansfisld and later Earl Mansfield, was a prestigious judge known for his moderation and tolerance that obtained the position of Chief Justice of the King's Bench.

40 lbid., p. 173.

41 The Catholic Relief Act.

42 lbid., p.203.

43 The trial of the Honourable George Gordon, commonly called Lord George Gordon, for high treason, at the Bar of the Court of King's Bench, on Monday, the 5th day of February, 1781, ... Rochester, 1781.

44 Hundreds of people died, more than one hundred Roman Catholic buildings were looted or burned (the homes of Mansfield and Savile among them), damages exceeded $£$ 180.000,00.

45 Charles Marie Raymond (or Charles Léopold), Duke of Aerschot and of Arenberg (1721-1778), son of Léopold Philippe de Ligne (1690-1754) who protected Rousseau and corresponded with Voltaire.

46 John Turberville Needham (1713-1781), English naturalist, and first Roman Catholic clergyman to become a member of the Royal Society of London (1768). Needham became director of the Imperial Academy of Sciences in Brussels.

47 Nathaniel Pigott (1725-1804), British astronomer, FRS since 1772 member of the Bruxelles Academy and correspondent of the Paris Academy of Sciences (1776)

48 Abbé Jean Chevalier, FRS sent a number of reports to the Royal Society during the 1750s describing astronomical observations made at Lisbon while he was presbyter of the Congregation of the Oratory there. Having later moved to Belgium, he was in 1772 appointed Librarian at the newly renovated Royal Library in Brussels, formerly the library of the Dukes of Burgundy, that had recently been converted into a public library.

49 Among these we just mention Joannes Franciscus Thijsbaert (1736-1825), professor of experimental physics at the University of Louvain.

50 Codefridus Gasparus Tackoen (or Godefroid Gaspar Tackoen) (1720-1788) lawyer, who worked at the Great Council of Mechelen (Malines) and later became counsellor.

51 A very old Collegiate church at Soignies near Enghien.

52 The process of his admission to the "Canonicat" de Soignies refers 27th of August 1785 as the date of the admission (after consultation of Their Royal Highnesses the Austrian Emperors), as the first choice among 34 candidates to the place left by death of the Dean, and the reason invoked had to do with his being "a distinguished sçavan."

53 Besides, we have only found the letters to Sanches from 1775 onwards (apart a few earlier ones) and certainly there existed many letters dated from the earlier decade.

54 She became known in history as Mary the Pious.

55 See note 48

56 We assume that in this sentence "martinian philosophy" refers to the philosophical ideas of Martin Luther. Madre Celestina (or Mother Celestine), is a character of Spanish and Portuguese 16th and 17th centuries literature that did marvellous things by means of witchcraft.

57 Optimistic character in Voltaire's Candide.

58 Again here we assume that the great Martin was meant to be Martin Luther.

59 He writes "ideas" in the Portuguese way.

60 lbid.

61 We know about these from the letters to his friend Sanches.

62 David Williams (1738-1816) a dissenting minister, founder of the Literary Fund, has been the author of a project of church reform, in a more tolerant basis, which attracted people like Benjamin Franklin, Joseph Banks, Daniel Solander among others.

$63 \mathrm{Mr}$. Gensfoutre = Mr. Nonentity. The person who invented the calumny was not identified.

64 Magellan was an assiduous guest of the Portuguese ambassador in London, Luís Pinto de Sousa, whom he admired very much. Here he says that what he was told would never be heard at the minister's house.

65 Sanbenito (Sp.) - yellow habit that those condemned by the Inquisition used when going to be set afire in the auto-da-fé.

66 João Paulo Bezerra de Seixas (1756-1817) had a degree in Law by Coimbra University, had several positions in Brazil and was Portuguese Representative in the United States (1801), in the Republic of Batavia (1802-1809) and then in Russia. He died in Brazil while deputy in the Ministry of War and Foreign Affairs of Portugal.

67 Possibly a doctor, J. Álvares who was a friend of Sanches in spite of having taken some attitudes that displeased him. Sanches refers to him a number of times in his Journal. We don't know why Magellan calls him crooked Álvares.

68 José Anastácio da Cunha (1744-1787) was a Portuguese mathematician (professor at Coimbra University) and poet who was persecuted by the Inquisition because of reading Voltaire and other forbidden authors, and imprisoned. He wrote some good books in mathematics. Later he was made professor and Director of the Casa Pia College in Lisbon. He died poor.

69 Magellan was among the fellows of the Royal Society that had signed motions to oppose the influence of the president (at the time Sir Joseph Banks) on the election or appointment of fellows. These contests occurred in 1784 and are described in several publications, such as KIPPIS, Andrew. Observations on the late contests in the Royal Society, D.D., RFS and SA, London, 1784

[Artigo recebido em 05/2008 | Aceito em 10/2009] 